\title{
Palaeoclimate analysis of the flora of the Klikov Formation, Upper Cretaceous, Czech Republic
}

\author{
ZUZANA VÁCHOVÁ \& JIŘÍ KVAČEK
}

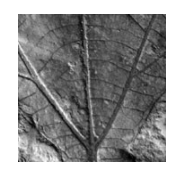

\begin{abstract}
The Late Cretaceous flora of the Klikov Formation (Upper Turonian-Santonian) in South Bohemia comprises 110 species representing pteridophytes, ferns, conifers, angiosperms, macro and mesofossils. Palaeoclimatic analysis of the Klikov Formation Flora using methods of Leaf Margin Analysis, Climate Leaf Analysis Multivariate Program (CLAMP) and the Nearest Living Relative allows us to conclude that this flora experienced a seasonally dry subtropical climate. Mean annual temperature is predicted to have been approximately $15^{\circ} \mathrm{C}$. Numerous charcoalified fossils strongly suggest frequent fires typical of a seasonally dry climate. $\bullet$ Key words: flora, Klikov Formation, Late Cretaceous, palaeoclimate, CLAMP, CoA.
\end{abstract}

VÁCHOVÁ, Z. \& KVAČEK, J. 2009. Palaeoclimate analysis of the flora of the Klikov Formation, Upper Cretaceous, Czech Republic. Bulletin of Geosciences 84(2), 257-268 (5 figures, 6 tables). Czech Geological Survey, Prague. ISSN 1214-1119. Manuscript received September 26, 2008; accepted in revised form April 8, 2009; published online May 15, 2009; issued June 30, 2009.

Zuzana Váchová, Charles University, Institute of Geology and Palaeontology, Albertov 6, 128 43, Prague 2, Czech Republic; zuzana.vachova@volny.cz•Jiři Kvaček, National Museum, Prague, 11579 Václavské náměstí 68, Prague 1, Czech Republic; jiri.kvacek@nm.cz.

Distribution and physiognomy of plants as well as plant assemblage characteristics are strongly influenced by climate. A number of studies have been published examining this relationship (Bailey \& Sinnot 1915; Wolfe 1979, 1993; Wing \& Greenwood 1993; Wilf 1997; Mosbrugger 1999; Uhl et al. 2007). Two different groups of palaeoclimatical methods are currently used to deduce the influence of climate on plant distribution and characteristics. The first group is based on analyses of morphological characters of woody dicot leaves (Bailay \& Sinnot 1915; Wolfe 1979, 1993; Wing \& Greenwood 1993; Wilf 1997). The second group is based on choosing the nearest living relatives of the fossil plants (Mosbrugger 1999, Mosbrugger \& Utescher 1997, Uhl 2006). Cretaceous plant assemblages contain numerous extinct family and genera. Interpretations of their palaeoecology usually require specific tools and methods. In this case study, we attempt to combine both of the above mentioned approaches: leaf morphology methods, which are usually used in studies of Cretaceous floras (Herman \& Spicer 1996; Herman \& Kvaček 2002, 2007; Herman et al. 2002; Kenedy et al. 2002); and the Nearest Living Relative method (NLR), which we used here experimentally bearing in mind that the method has its limits with Cretaceous floras and can produce larger deviations than predicted. Scarcity of living relatives and the degree of relatedness between recent and Cretaceous taxa are the largest problems when using the Nearest Living Relative method. However, we attempted to use both methods in order to demonstrate a comparison between the two. This could help us in understanding the applicability and comparability of both palaeoecological methods in relation to Cretaceous plant assemblages. A comparison of several methods, based on different primary data, generally gives higher credibility of final results. However, we understand that the degree of accuracy of these methods applied to Cretaceous plant assemblages cannot be as high as is usual in the Tertiary. The main problem with the NLR method in Cretaceous plant assemblages is the difficulty of determining the nearest living relative. Another factor decreasing the accuracy of our data is the poor preservation of leaf impressions from the Klikov Formation.

\section{Geological setting}

The fossil leaves in this study come from the Klikov Formation, basal member of the South Bohemian Basins. The South Bohemian Basins consist of two parts, the Budějovice and Třeboň Basins, separated from each other by Lišov Horst (Rudolfov Ridge). The basins together occupy an area of $2300 \mathrm{~km}^{2}$ (Fig. 1). Sedimentation in the basins began in the Late Cretaceous and continued intermittently 


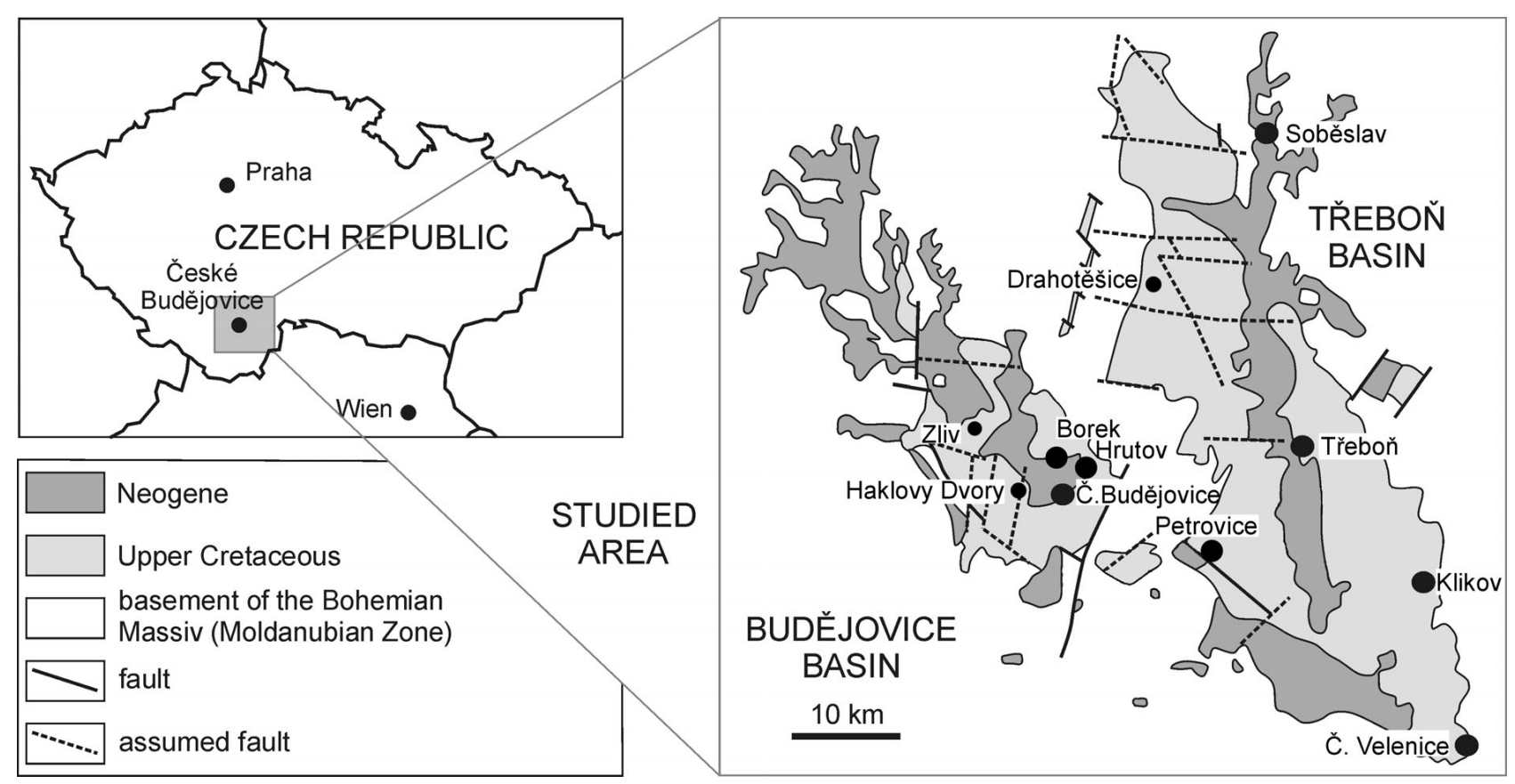

Figure 1. Geological map of South Bohemian Basins according to Slánská (1976) and Ševčík (2007) and position of South Bohemian Basins in the Czech Republic.

until the Pliocene (Malecha et al. 1962, Slánská 1974, Ševčík et al. 2007).

The sedimentary succession of the Klikov Formation (Upper Turonian-Santonian) was classified according to Slánská (1974, 1976) who recognized three lithological types that constituted an irregular cyclical sequence. The lithological types are: A - light grey (or greenish light grey, yellowish - grey) sandstone beds; B - red beds; and $\mathrm{C}$ - grey beds. The red beds consist of poorly sorted sandstones, sandy mudstones or sandy claystones. The grey beds consist of sandstones or claystones, with variable amounts of carbonised plant debris and pigment. Plant fossils occur predominantly in the grey beds, but are also present in the red beds. Sedimentary sequences are interpreted as successions of fluvial and lacustrine deposits (Slánská 1976).

\section{Fossil flora}

The flora of the Klikov Formation represents one of the most interesting Late Cretaceous floras in Central Europe. This flora includes macrofossils (leaves), mesofossils (fruits and seeds) and microfossils (pollen), and has been a focus of scientific interest since the $19^{\text {th }}$ century. The main period of intensive study was from the 1950's to the 1980's. The oldest descriptions of this fossil flora were done by Ettingshausen (1852). The limited number of leaf impressions that Ettingshausen (1852) identified indicated that the flora was Tertiary in age. Cretaceous age for the flora was first proposed by Němejc (1938), who interpreted it as Cenomanian. However, micropaleontological studies in the early sixties of the last century by Pacltová $(1958 b, 1961)$ revealed a Senonian age. Upper Turonian-Santonian age of the Klikov Formation was established by Pacltová (1981) and supported by Knobloch (1985). We support an Upper Turonian-Santonian age for the Klikov Formation sensu Knobloch (1985), which was based on a comparison of palynology, carpology and macroflora. Fossil leaves from the location were described by Němejc (1961), Knobloch (1964) and Němejc \& Kvaček (1975). Fruits and seeds were studied in detail by Knobloch \& Mai (1984, 1986, 1991). Palynological research was carried out mostly by Pacltová (1955, 1958a, b, 1961, 1981; Němejc \& Pacltová 1956). Palaeoecological aspects of the flora were briefly mentioned in palaeoecological comparisons with other Euro-Asian localities by Herman et al. (2004).

Angiosperm remains (leaves and reproductive structures) represent over $90 \%$ of the Klikov flora. Approximately 1000 dicotyledonous angiosperm leaf impressions and compressions have been recorded from the South Bohemian Cretaceous, which were assigned to 23 species (Figs 2, 5). Reproductive structures of angiosperms were assigned to ca 90 species (Knobloch \& Mai 1986, 1991). Specimens examined for this study are housed in the collections of the National Museum, and the Czech Geological Survey, both in Prague. Most of the leaf fossils are fragmentary; however, many specimens have well preserved cuticle. Reproductive structures are usually preserved as lignified or charcoalified mesofossils (Table 1). 
Table 1. Occurrence of selected taxa from Klikov Formation used for palaeoclimate analysis. A - Branišov GB-3, B - Břidlice L-XIII, C - Borek u Českých Budějovic, D - České Budějovice ČB-4, E - České Budějovice - Budvar, F - Drahotěšice, G - Haklovy dvory Br21/58, H - Haklovy dvory ČB2, I - Hluboká nad Vltavou, J - Hrutov, K - Klikov, L - Lomnice n. L. V-10, M - Nedabyle TsV-6, N-Opatovice H1-1, O - Třebeč Tj-4a, P - Třebeč TjSv-5, Q - Petrovice, R - Vyškov, S - Vráto Vo-38-Vo-66, T - Zliv - Řídká blana.

\begin{tabular}{|c|c|c|c|c|c|c|c|c|c|c|c|c|c|c|c|c|c|c|c|c|}
\hline & A & B & $\mathrm{C}$ & D & E & $\mathrm{F}$ & $\mathrm{G}$ & $\mathrm{H}$ & I & $\mathrm{J}$ & $\mathrm{K}$ & $\mathrm{L}$ & $\mathrm{M}$ & $\mathrm{N}$ & $\mathrm{O}$ & $\mathrm{P}$ & Q & $\mathrm{R}$ & $S$ & $\mathrm{~T}$ \\
\hline Araliophyllum elongatum Němejc & & & & & & & & & & & $\mathrm{x}$ & & & & & & & & & \\
\hline Cocculophyllum extinctum (Velenovský) Němejc \& Kvaček & & & & & & & & & & & & & & & & & & & & $\mathrm{x}$ \\
\hline Debeya cf. coriacea (Velenovský) Knobloch & & & & & & & & & & & & & & & & & & & & $\mathrm{X}$ \\
\hline Debeya haldemiana (Saporta \& Marion) Knobloch & & & & & & & & & & & $\mathrm{x}$ & & & & & & & & & $\mathrm{x}$ \\
\hline Debeya insignis (Hosius \& Marck) Knobloch & & & $\mathrm{x}$ & & & & & & & & $\mathrm{X}$ & & & & & & $\mathrm{x}$ & & & $\mathrm{x}$ \\
\hline Debeya lusitanica (Teixeira) Knobloch & & & & & & & & & & & $\mathrm{x}$ & & & & & & & $\mathrm{x}$ & & \\
\hline Dicotylophyllum saliciforme Němejc & & & & & & & & & & & $\mathrm{x}$ & & & & & & & & & \\
\hline Dicotylophyllum sp. Laurophylum affine Velenovský & & & & & & & & & & $\mathrm{x}$ & $\mathrm{x}$ & & & & & & $\mathrm{x}$ & & & $\mathrm{X}$ \\
\hline Dicotylophyllum sp. A & & & & & & & & & & & & & & & & & & & & $\mathrm{x}$ \\
\hline Dicotylophyllum sp. B & & & & & & & & & & & $\mathrm{x}$ & & & & & & & & & $\mathrm{X}$ \\
\hline Dicotylophyllum sp. C & & & & & & & & & & & & & & & & & & & & $\mathrm{X}$ \\
\hline Dicotylophyllum sp. D & & & & & & & & & & $\mathrm{x}$ & & & & & & & & & & $\mathrm{x}$ \\
\hline Dicotylophyllum sp. E & & & & & & & & & & & & & & & & & & & & $\mathrm{x}$ \\
\hline Dicotylophyllum sp. F & & & & & & & & & & & & & & & & & & & & $\mathrm{x}$ \\
\hline Dicotylophyllum sp. G & & & & & & & & & & & $\mathrm{x}$ & & & & & & & & & \\
\hline Dicotylophyllum sp. H & & & & & & & & & & & & & & & & & & & & $\mathrm{x}$ \\
\hline Ettingshausenia cf. laevis (Velenovský) J. Kvaček \& Váchová & & & & & & & & & & & $\mathrm{x}$ & & & & & & & $\mathrm{x}$ & & $\mathrm{x}$ \\
\hline Ettingshausenia senonensis (Knobloch) J. Kvaček \& Váchová & & & & & & $\mathrm{x}$ & $\mathrm{x}$ & & & & $\mathrm{x}$ & & & & & & $\mathrm{x}$ & $\mathrm{x}$ & & $\mathrm{x}$ \\
\hline Liriodendron papilliformis Knobloch \& Mai & & & & $\mathrm{x}$ & & & & & & & & & & $\mathrm{x}$ & & & & & & \\
\hline Myricophyllum serratum (Velenovský) Němejc & & & & & & & & & & $\mathrm{x}$ & $\mathrm{x}$ & & & & & & & & & $\mathrm{x}$ \\
\hline Proteophyllum laminarium Velenovský & & & & & & & & & $\mathrm{x}$ & $\mathrm{x}$ & $\mathrm{X}$ & & & & & & & $\mathrm{x}$ & $\mathrm{x}$ & $\mathrm{x}$ \\
\hline Proteophyllum lanceolatum Němejc \& Z. Kvaček & & & & & & & & & & & $\mathrm{x}$ & & & & & & $\mathrm{x}$ & & & $\mathrm{x}$ \\
\hline Quercophyllum pseudodrymejum (Velenovský) Němejc & & & & & & & & & & & $\mathrm{x}$ & & & & & & & & & $\mathrm{x}$ \\
\hline Qurecophyllum triangulodentatum Knobloch & & & & & & & & & & & & & & & & & $\mathrm{x}$ & & & \\
\hline Sabia menispermoides Knobloch \& Mai & & & & & $\mathrm{X}$ & & & & & & & & & & & & & & & \\
\hline Saurauia alenae Knobloch \& Mai & $\mathrm{x}$ & $\mathrm{x}$ & & & & & & $\mathrm{x}$ & & & & $\mathrm{x}$ & $\mathrm{x}$ & $\mathrm{x}$ & $\mathrm{x}$ & $\mathrm{x}$ & & & $\mathrm{x}$ & \\
\hline Saurauia antiqua Knobloch \& Mai & & & & & & & & & & & & & & & $\mathrm{x}$ & $\mathrm{x}$ & & & & \\
\hline
\end{tabular}

\section{Methods}

For palaeoclimatic reconstruction and interpretation of the climate which existed during sedimentation of the Klikov Formation, we have used two major methods: Nearest Living Relative (NLR) and leaf physiognomy. The Nearest Living Relative methods (Heer 1855-1859, Mosbrugger 1999) are based on climate variables necessary for growth of the nearest living relatives of the fossil plants under study. Quantitative taxa-based approaches of NLR methods included a coexistence approach (CoA) by Mosbruger \& Utescher (1997) as one of the new versions of NLR. Leaf physiognomy methods are based on correlation between climate variables and leaf physiognomy. Two methods are usually applied: Leaf Margin Analysis (LMA) (Bailay \& Sinnot 1915, Wing \& Greenwood 1993, Wilf 1997, Wilf et al. 1998); and Climate Leaf Analysis Multivariate Program
(CLAMP) (Wolfe 1990, 1993; Spicer 2006; Yang et al. 2007). CLAMP is a far more precise method for Cretaceous floras, because it does not require living relatives which are extremely uncommon for Cretaceous taxa.

CoA - For the coexistence approach, a dataset [PALAEOFLORA (Utescher 2006)] has been developed containing over 800 Tertiary taxa together with relevant records of mean annual temperatures, cold month mean temperatures and warm month mean temperatures.

LMA - Leaf Margin Analysis is based directly on the work of Bailay \& Sinnot (1915), who were the first researches to find a robust relationship between leaf morphology and climate. Wing \& Greenwood (1993) refined this method, which now has the advantage of scoring only one character. They defined a mathematical formula for calculation of mean annual tem- 
Table 2. Selected taxa from Klikov Formation. CLAMP - taxa used for CLAMP. CoA - taxa used coexistence approach. NLR - taxa identified as nearest living relatives.

\begin{tabular}{|c|c|c|c|c|}
\hline & plant organ & CLMAP & $\mathrm{CoA}$ & NLR \\
\hline Araliophyllum elongatum Němejc & leaf & $\mathrm{x}$ & & \\
\hline Cocculophyllum extinctum (Velenovský) Němejc \& Kvaček & leaf & $\mathrm{x}$ & & \\
\hline Debeya cf. coriacea (Velenovský) Knobloch & leaf & $\mathrm{x}$ & & \\
\hline Debeya haldemiana (Saporta \& Marion) Knobloch & leaf & $\mathrm{x}$ & & \\
\hline Debeya insignis (Hosius \& Marck) Knobloch & leaf & $\mathrm{x}$ & & \\
\hline Debeya lusitanica (Teixeira) Knobloch & leaf & $\mathrm{x}$ & & \\
\hline Dicotylophyllum saliciforme Němejc & leaf & $\mathrm{x}$ & & \\
\hline Dicotylophyllum sp. Laurophylum affine Velenovský & leaf & $\mathrm{x}$ & & \\
\hline Dicotylophyllum sp. A & leaf & $\mathrm{x}$ & & \\
\hline Dicotylophyllum sp. B & leaf & $\mathrm{x}$ & & \\
\hline Dicotylophyllum sp. C & leaf & $\mathrm{x}$ & & \\
\hline Dicotylophyllum sp. D & leaf & $\mathrm{x}$ & & \\
\hline Dicotylophyllum sp. E & leaf & $\mathrm{x}$ & & \\
\hline Dicotylophyllum sp. F & leaf & $\mathrm{x}$ & & \\
\hline Dicotylophyllum sp. G & leaf & $\mathrm{x}$ & & \\
\hline Dicotylophyllum sp. H & leaf & $\mathrm{x}$ & & \\
\hline Ettingshausenia cf. laevis (Velenovský) Kvaček \& Váchová & leaf & $\mathrm{x}$ & $\mathrm{x}$ & Platanus sp. \\
\hline Ettingshausenia senonensis (Knobloch) Kvaček \& Váchová & leaf & $\mathrm{x}$ & $\mathrm{x}$ & Platanus sp. \\
\hline Liriodendron papilliformis Knobloch \& Mai & seed & & $\mathrm{x}$ & Liriodendron sp. \\
\hline Myricophyllum serratum (Velenovský) Němejc & leaf & $\mathrm{x}$ & & \\
\hline Proteophyllum laminarium Velenovský & leaf & $\mathrm{x}$ & & \\
\hline Proteophyllum lanceolatum Němejc \& Z. Kvaček & leaf & $\mathrm{x}$ & & \\
\hline Quercophyllum pseudodrymejum (Velenovský) Němejc & leaf & $\mathrm{x}$ & & \\
\hline Qurecophyllum triangulodentatum Knobloch & leaf & $\mathrm{x}$ & & \\
\hline Sabia menispermoides Knobloch \& Mai & seed & & $\mathrm{x}$ & Sabia sp. \\
\hline Saurauia alenae Knobloch \& Mai & endocarp & & $\mathrm{x}$ & Saurauia sp. \\
\hline Saurauia antiqua Knobloch \& Mai & endocarp & & $\mathrm{x}$ & Saurauia sp. \\
\hline
\end{tabular}

perature (MAT). Wilf (1997) tested the LMA method against the CLAMP modern-plant database as well as with independently collected data from modern floras (mostly herbarium specimens); he found good correlations between leaf margin type and mean annual temperature, and between leaf area and mean annual precipitation. The temperature is correlated with the percentage of entire margined species in a flora. The disadvantage of the method is its low accuracy and evaluation using only one parameter (MAT).
CLAMP - Climate Leaf Analysis Multivariate Program is a widely used multivariate statistical technique for obtaining palaeoclimatic information (Wolf 1990, 1993; Kovach \& Spicer 1995; Wolf \& Spicer 1999; Spicer 2000; Kvaček \& Teodoridis 2007). The paradigm used by CLAMP correlates the physiognomy of woody dicot leaves with the temperature and amount of precipitation. CLAMP has been used effectively for fossil floras up to 100 million years old (Herman \& Spicer 1996, Herman et

Figure 2. Angiosperm fossil leaves of the Klikov Formation. Scale bar $-1 \mathrm{~cm} \cdot \bullet$ A - Dicotylophyllum sp., Zliv - Řídká Blana, F 1728. • B - Dicotylophyllum sp., Zliv - Ř́dká Blana, F 1566. • C - Proteophyllum laminarium Velenovský, Zliv - Řídká Blana, F 1674. • D - Quercophyllum pseudodrymejum (Velenovský) Němejc, Klikov, F 0070. • E - Qurecophyllum triangulodentatum Knobloch, Pertovice, ČGU 809. • F - Debeya cf. coriacea (Velenovský) Knobloch, Zliv - Řídká Blana, F 1612. • G - Dicotylophyllum saliciforme Němejc, Klikov, F1562. • H - Proteophyllum lanceolatum Němejc \& Z. Kvaček, holotype, Zliv - Řídká Blana, F 1630. • I - Ettingshausenia cf. laevis (Velenovský) J. Kvaček \& Váchová, Klikov, F 0041. • J - Araliophyllum elongatum Němejc, lektotyp, Klikov, F 0028. • K - Cocculophyllum extinctum (Velenovský) Němejc \& Z. Kvaček, Zliv Řídká Blana, F 1799. • L - Debeya haldemiana (Saporta \& Marion) Knobloch, Klikov, F 0045. • M - Ettingshausenia senonensis (Knobloch) J. Kvaček \& Váchová, Zliv - Ǩídká Blana, ČGU P 1820. • N - Debeya insignis (Hosius \& Marck) Knobloch, Borek u Českých Budějovic, F1730. • O - Dicotylophyllum sp., Zliv - Ř́ídká Blana, F 1632. 
Zuzana Váchová \& Jiří Kvaček • Palaeoclimate analysis of the flora of the Klikov Formation, Cretaceous
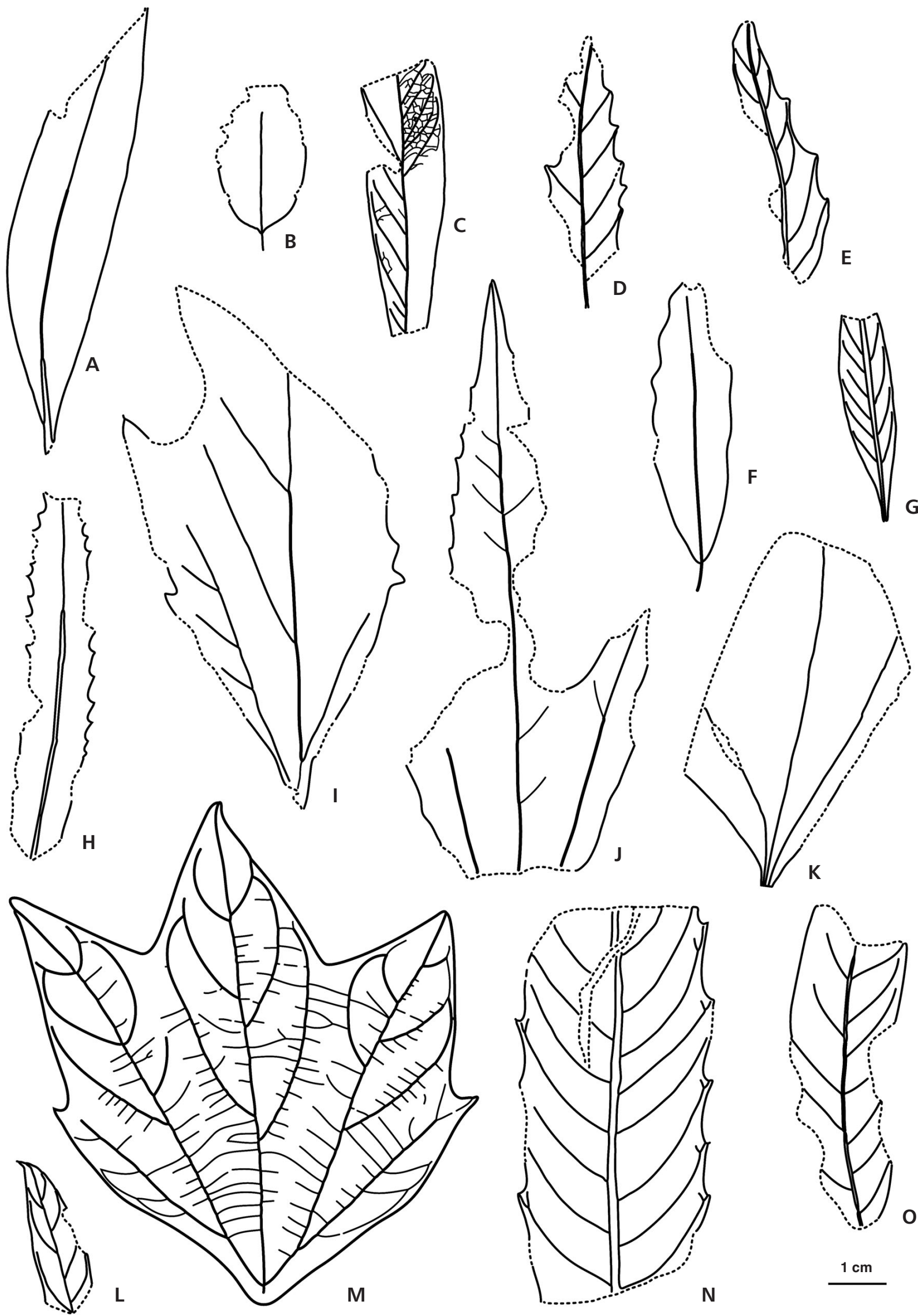


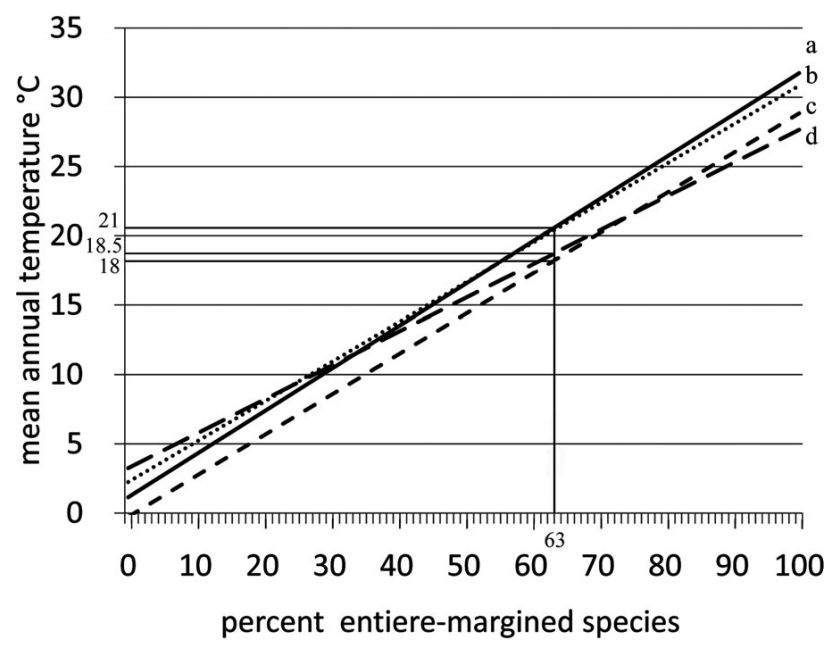

Figure 3. Leaf Margin Analysis. LMAT calculated for $63 \%$ of entire marinate leaves. a - plot according to Wolfe 1979 (Wing 1993), b - plot according to Wilf 1997 (Wilf 1997), c - plot according to Wolfe 1993, data for CLAMP were used (Wilf 1997), d - plot according to Wolfe (1993) data for CLAMP were used when 32 sites with the coldest winter temperatures were removed (Wilf 1997).

al. 2002, Kennedy et al. 2002, Hayes et al. 2006). It works well for leaf palaeoassemblages with more than 20 morphospecies of woody dicot leaves.

In CLAMP the architecture of woody dicot leaves from extant vegetation growing under known climatic conditions is used as a reference data set. The architecture of leaves found in a fossil assemblage is then compared with this data set. There are now several of these datasets which vary in size, geographical and climatic coverage. We selected comparable and appropriate datasets of 173 and 144 modern vegetation sites. Most of these sites are located in the Northern Hemisphere (dataset PHYSG3AR) and are scored for 31 leaf characters and correlated with 8 climate variables (Wolfe 1993, 1995; Herman \& Spicer 1996, 1997); see also http://tabitha.open.ac.uk/spicer/CLAMP/Clampset1.html. These variables are: mean annual temperature (MAT), warm month mean temperature (WMMT), cold month mean temperature (CMMT), length of the growing season (GROWSEAS), growing season precipitation (GSP), mean monthly growing season precipitation (MMGSP), precipitation during the 3 consecutive wettest months (3-WET) and precipitation during the 3 consecutive driest months (3-DRY).

The CANOCO program, using Canonical Correspondence Analysis (Ter Baark 1986) is a direct ordination method used here to order site, leaf character and environmental data simultaneously in multidimensional space; sites are ordered by their character scores, characters are ordered by their distribution among the sites. Thus, sites are arranged relative to one another in multidimensional space using the physiognomic characters of the vegetation at that site; environmental data are not used to position the sites.
Table 3. Scoring results (percentage of characters preserved) for CLAMP analysis.

\begin{tabular}{|c|c|c|}
\hline foliar physiognomic characters & & Klikov \\
\hline \multirow[t]{7}{*}{ margin character states } & lobed & $13 \%$ \\
\hline & no teeth & $63 \%$ \\
\hline & teeth regular & $25 \%$ \\
\hline & teeth close & $10 \%$ \\
\hline & teeth round & $4 \%$ \\
\hline & teeth acute & $3 \%$ \\
\hline & teeth compound & $0 \%$ \\
\hline \multirow[t]{9}{*}{ size character states } & nanophyll & $0 \%$ \\
\hline & leptophyll I & $0 \%$ \\
\hline & leptophyll II & $2 \%$ \\
\hline & microphyll I & $23 \%$ \\
\hline & microphyll II & $46 \%$ \\
\hline & microphyll III & $19 \%$ \\
\hline & mesophyll I & $9 \%$ \\
\hline & mesophyll II & $1 \%$ \\
\hline & mesophyll III & $0 \%$ \\
\hline \multirow[t]{4}{*}{ apex character states } & apex emarg. & $0 \%$ \\
\hline & apex round & $0 \%$ \\
\hline & apex acute & $100 \%$ \\
\hline & apex atten. & $0 \%$ \\
\hline \multirow[t]{3}{*}{ base character states } & base cordate & $0 \%$ \\
\hline & base round & $2 \%$ \\
\hline & base acute & $98 \%$ \\
\hline \multirow[t]{5}{*}{ length to width character states } & $\mathrm{L}: \mathrm{W}<1: 1$ & $0 \%$ \\
\hline & $\mathrm{L}: \mathrm{W} 1-2: 1$ & $26 \%$ \\
\hline & L:W $2-3: 1$ & $0 \%$ \\
\hline & L:W 3-4 : 1 & $11 \%$ \\
\hline & $\mathrm{L}: \mathrm{W}>4: 1$ & $63 \%$ \\
\hline \multirow[t]{3}{*}{ shape character states } & obovate & $19 \%$ \\
\hline & elliptic & $81 \%$ \\
\hline & ovate & $0 \%$ \\
\hline total number of species & & 23 \\
\hline
\end{tabular}

\section{Results}

Leaf Margin Analysis of 23 dicot leaf morphotypes from the Klikov Formation flora (Table 2) shows that $63 \%$ of morphotypes have entire-margined leaves.

For LMA calculation four different mathematical formulas were used. "P" is in all the formulas, and represents percentage of entire-margined leaves. The first formula, LMAT $=1.141+(\mathrm{P} \times 0.306)($ Fig. 3$)$, was published by Wing \& Greenwood (1993), and is based on data collected by Wolfe (1979). When this formula is applied to $63 \%$, the value of MAT is $20.5^{\circ} \mathrm{C}$. The second formula, LMAT $=$ $2.24+(\mathrm{P} \times 0.286)($ Fig. 3), was published by Wilf $(1997)$, 
Table 4. Results of CLAMP, Klikov ecosystem (Upper Turonian-Santonian).

\begin{tabular}{|c|c|c|c|c|}
\hline & $\begin{array}{l}\text { Standard deviation } \\
\text { for A } 173\end{array}$ & $\begin{array}{l}\text { Klikov - A } 173 \\
\text { recent sites }\end{array}$ & $\begin{array}{l}\text { Standard deviation } \\
\text { for B } 144\end{array}$ & $\begin{array}{l}\text { Klikov - B } 144 \\
\text { recent sites }\end{array}$ \\
\hline MAT ${ }^{\circ} \mathrm{C}-$ mean annual temperature & 1.72 & 14.19 & 1.17 & 11.82 \\
\hline WMMT ${ }^{\circ} \mathrm{C}$ - warm month mean temperature & 1.80 & 23.87 & 1.58 & 14.72 \\
\hline $\mathrm{CMMT}^{\circ} \mathrm{C}-$ cold month mean temperature & 2.54 & 5.66 & 1.88 & 8.02 \\
\hline GROWSEAS months - length of the growing season & 0.85 & 8.04 & 0.70 & 6.88 \\
\hline GSP mm - growing season precipitation & 318 & 808.2 & 336 & 1332.2 \\
\hline MMGSP mm - mean monthly growing season precipitation & 37 & 104.6 & 37 & 108.5 \\
\hline 3-WET $\mathrm{mm}$ - precipitation during the 3 consecutive wettest months & 138 & 433.7 & 140 & 552.8 \\
\hline 3-DRY mm - precipitation during the 3 consecutive driest months & 89 & 189.4 & 93 & 93.9 \\
\hline
\end{tabular}

mean annual precipitacion

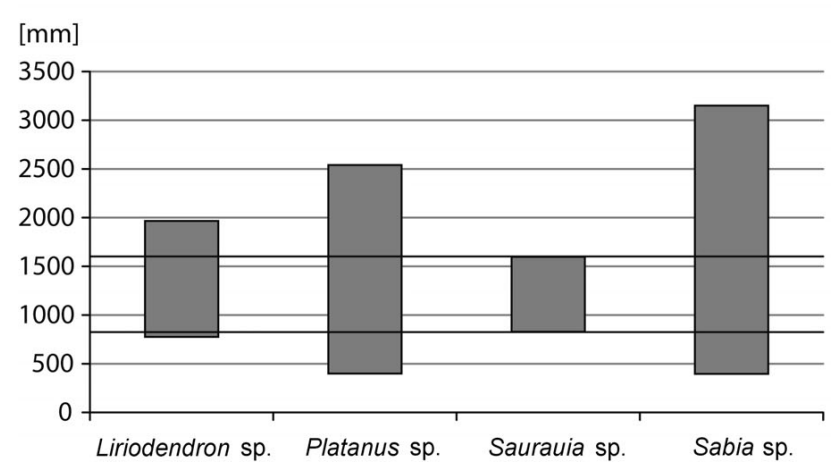

$\left[{ }^{\circ} \mathrm{C}\right] \quad$ temp. coldest month

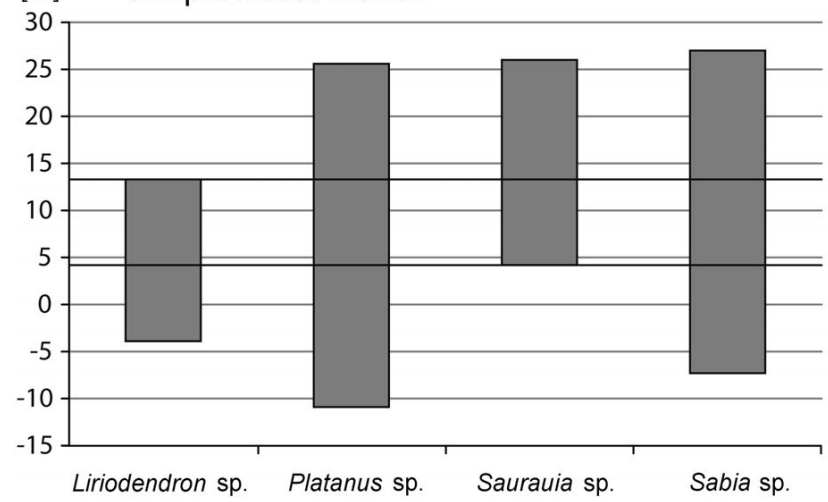

$\left[{ }^{\circ} \mathrm{C}\right] \quad$ mean annual temperature

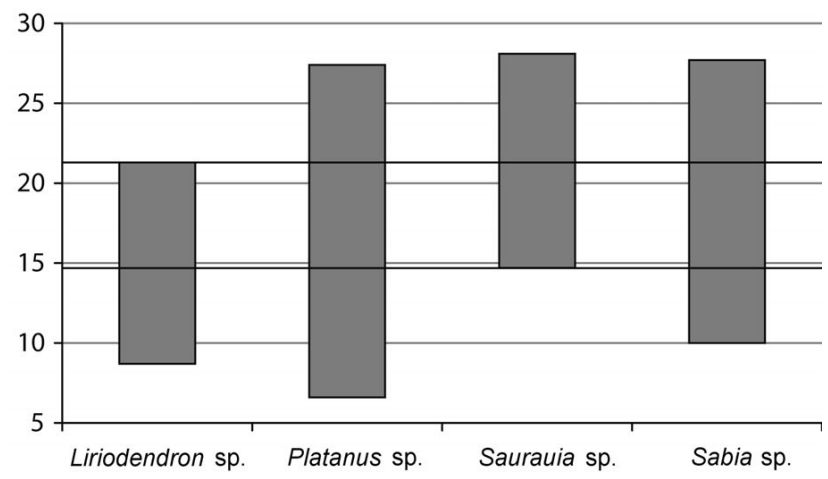

$\left[{ }^{\circ} \mathrm{C}\right] \quad$ temp. warmest month

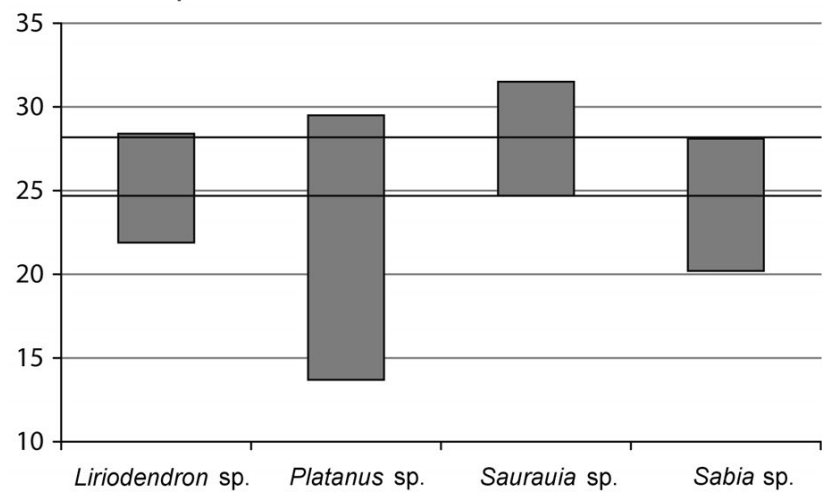

Figure 4. Summarised data from co-existence approach. Four taxa were used for the coexistence approach (Platanus-Ettingshausenia, Liriodendron, Sabia, Saurauia). The value limits the interval of coexistence.

and is based on data collected by Wilf (1997). When formula two is applied to $63 \%$, the value of MAT is $20.2{ }^{\circ} \mathrm{C}$. The third formula, LMAT $=(\mathrm{P} \times 0.291)-0.226($ Fig. 3), was published by Wilf (1997), and is based on data collected by Wolfe (1993) for CLAMP analysis. When this third formula is applied to $63 \%$, the value of MAT is $18.0^{\circ} \mathrm{C}$. The fourth formula, $\mathrm{LMAT}=(\mathrm{P} \times 0.244)+3.25$ (Fig. 3), was published by Wilf (1997), and is based on data collected by Wolfe (1993) for CLAMP analysis, but only for a warm climate. When formula four is applied to $63 \%$, the value of MAT is $18.5^{\circ} \mathrm{C}$. Sampling deviation is greater than $3{ }^{\circ} \mathrm{C}$ (Wilf 1997); however, with the poor preservation of plant fossils from the Klikov Formation, our deviation could be even larger.

In the present study, 23 leaf morphotypes (Table 2) were scored for 32 characters (Table 3). CLAMP analysis of the flora of the Klikov Formation revealed MAT of $14{ }^{\circ} \mathrm{C}$, WMMT $24{ }^{\circ} \mathrm{C}$, CMMT $6{ }^{\circ} \mathrm{C}$, GROWSEAS 8 months, GSP $800 \mathrm{~mm}$, MMGSP $100 \mathrm{~mm}$, 3-WET $430 \mathrm{~mm}$ and 3-DRY $190 \mathrm{~mm}$. The assemblage was scored 
Table 5. Preliminary results of CLAMP, Klikov ecosystem, published by Herman et al. (2002).

\begin{tabular}{|c|c|c|}
\hline & $\begin{array}{l}\text { standard } \\
\text { deviation }\end{array}$ & $\begin{array}{c}\text { Klikov, } \\
\text { Zliv, } \\
\text { Hluboká }\end{array}$ \\
\hline 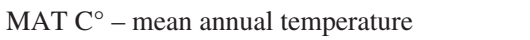 & 1.8 & 15.6 \\
\hline $\mathrm{WMMT}^{\circ}$ - warm month mean temperature & 3.1 & 22.2 \\
\hline $\mathrm{CMMT} \mathrm{C}^{\circ}-$ cold month mean temperature & 3.3 & 9.0 \\
\hline $\begin{array}{l}\text { GROWSEAS months - length of the growing } \\
\text { season }\end{array}$ & 1.1 & 8.7 \\
\hline GSP mm - growing season precipitation & 280 & 780 \\
\hline $\begin{array}{l}\text { MMGSP mm - mean monthly growing season } \\
\text { precipitation }\end{array}$ & 23 & 88.6 \\
\hline $\begin{array}{l}\text { 3-DRY mm - precipitation during the } 3 \\
\text { consecutive driest months }\end{array}$ & 70 & 144.1 \\
\hline
\end{tabular}

Table 6. Klikov ecosystem - major palaeoclimatic parameters. LMA - according to formula published by Wilf (1997), based on data collected by Wolfe (1993) for CLAMP analysis. CLAMP - the assemblage was scored according to 173 recent sites. CoA - four taxa (PlatanusEttingshausenia, Liriodendron, Sabia, Saurauia) were used for the coexistence approach.

\begin{tabular}{lccc}
\hline & LMA & CLAMP & coexistence approach \\
\hline MAT ${ }^{\circ} \mathrm{C}$ & 18.5 & 15 & $15-21$ \\
WMMT $^{\circ} \mathrm{C}$ & & 24 & $24-28$ \\
$\mathrm{CMMT}^{\circ} \mathrm{C}$ & 6 & $5-15$ \\
$\mathrm{GSP}^{\mathrm{mm}}$ & & 800 & $900-1600$ \\
\hline
\end{tabular}

according to 173 recent sites. Calibrating our CLAMP analysis with a dataset of 144 recent localities, we obtained extremely low temperatures MAT $12{ }^{\circ} \mathrm{C}$, WMMT $15^{\circ} \mathrm{C}$, CMMT $8{ }^{\circ} \mathrm{C}$. Other data are as follows: GROWSEAS 7 months, GSP $1300 \mathrm{~mm}$, MMGSP $100 \mathrm{~mm}$, 3-WET $550 \mathrm{~mm}$ and 3-DRY $100 \mathrm{~mm}$ (Table 4). As is the case with other proxy studies of this flora, we do not give high credibility to the extremely low temperatures resulting from these calculations with a dataset of 144 sites.

Most of the living relatives of the studied plants occur in regions with CMMT well below $0{ }^{\circ} \mathrm{C}$ (Fig. 4). The only plant which shows CMMT above freezing is the genus Saurauia (Fig. 4). However, many species of this genus are freeze hardy (Mai 1970, Soejarto 1980, Behera et al. 2002, Anonymus 2008). Therefore, we decided to use the data set of 173 recent localities recommended for calculation of palaeoclimatic variables of temperate floras.

Four taxa were used for the coexistence approach (Platanus-Ettingshausenia, Liriodendron, Sabia, Saurauia).

Leaves of Ettingshausenia senonensis (Knobloch) J. Kvaček \& Váchová and Ettingshausenia laevis (Velenovský) J. Kvaček \& Váchová are common in the Klikov Formation. They are preserved as leaf compressions and impressions. The Cretaceous genus Ettingshausenia is associated with the recent family Plataneaceae (Kvaček \& Váchová 2006). Extant members of this family are widespread in warm-temperate regions of the Northern Hemisphere, but they also grow in the subtropics. Cretaceous representatives of this family are also known from regions characterised by a temperate climate.

Liriodendron, Saurauia and Sabia are preserved as charcoalified seeds.

Sabiaceae - the genus Sabia is often used for Tertiary NLR analyses. Sabia menispermoides Knobloch \& Mai represents one of the earliest records of the genus (Knobloch \& Mai 1986). The recent Sabiaceae are native to warm tropical temperate regions of southern Asia and the Americas.

Saurauiaceae - the record of the recent Saurauia Willdenow in the Klikov Formation is one of the earliest for the family. Tertiary species of Saurauia (S. poolensis, $S$. crassisperma and $S$. subhercynica) are very similar to the recent species $S$. nudiflora (Mai 1970). Cretaceous $S$. antiqua has characters very similar to $S$. poolensis (Chandler) Mai, but it is smaller and has a longer raphe (Knobloch \& Mai 1986). The recent genus Saurauia has approximately 250 species distributed throughout the tropics and subtropics of Asia and both South and Central America.

Magnoliaceae - the genus Liriodendron is known since the Cenomanian and is a common element of Cretaceous floras (Frumin \& Friis 1999). Material for this study is represented by a single specimen. In this case, we relied on the determination by Knobloch \& Mai (1986), who studied more seeds. There are two recent species in the genus: Liriodendron chinense, native to China and Vietnam; and Liriodendron tulipifera, native to North America. Representatives of this genus grow in subtropical to temperate climates (Beck 1990).

The data and results of our determination of CoA are summarised in Fig. 4. We have identified MAT values from $15^{\circ} \mathrm{C}$ to $21{ }^{\circ} \mathrm{C}$ and $\mathrm{CMMT}$ values from $5{ }^{\circ} \mathrm{C}$ to $15^{\circ} \mathrm{C}$. The

Figure 5. The angiosperm fossil leaves of the Klikov Formation. Scale bar - $1 \mathrm{~cm}$. A - Ettingshausenia senonensis (Knobloch) J. Kvaček \& Váchová, Zliv - Ř́dká Blana, ČGU P 1820. • B - Ettingshausenia senonensis (Knobloch) J. Kvaček \& Váchová, holotype, Zahájí Za1, depth 38.5 m, ČGU P 2960. - C - Quercophyllum pseudodrymejum (Velenovský) Němejc, Zliv - Řídká Blana, F 1702. • D - Proteophyllum laminarium Velenovský, Zliv - Ř́iká Blana, F 1674. • E - Proteophyllum lanceolatum Němejc \& Z. Kvaček, holotype, Zliv - Ř́dká Blana, F 1630. • F - Debeya cf. coriacea (Velenovský) Knobloch, Zliv - Rídká Blana, F 1612.• G - Dicotylophyllum sp. C, Zliv - Ř́dká Blana, F 1728. • H - Cocculophyllum extinctum (Velenovský) Němejc \& Z. Kvaček, Zliv - Ř́dká Blana, F 1799. • I - Araliophyllum elongatum Němejc, Klikov, F 0033. • J - Araliophyllum elongatum Němejc, lectotype, Klikov, F 0028. • K - Dicotylophyllum sp., Zliv - Rídká Blana, F 1632. • L - Dicotylophyllum sp., Zliv - Ř́ídká Blana, F1567. 
Zuzana Váchová \& Jiří Kvaček • Palaeoclimate analysis of the flora of the Klikov Formation, Cretaceous
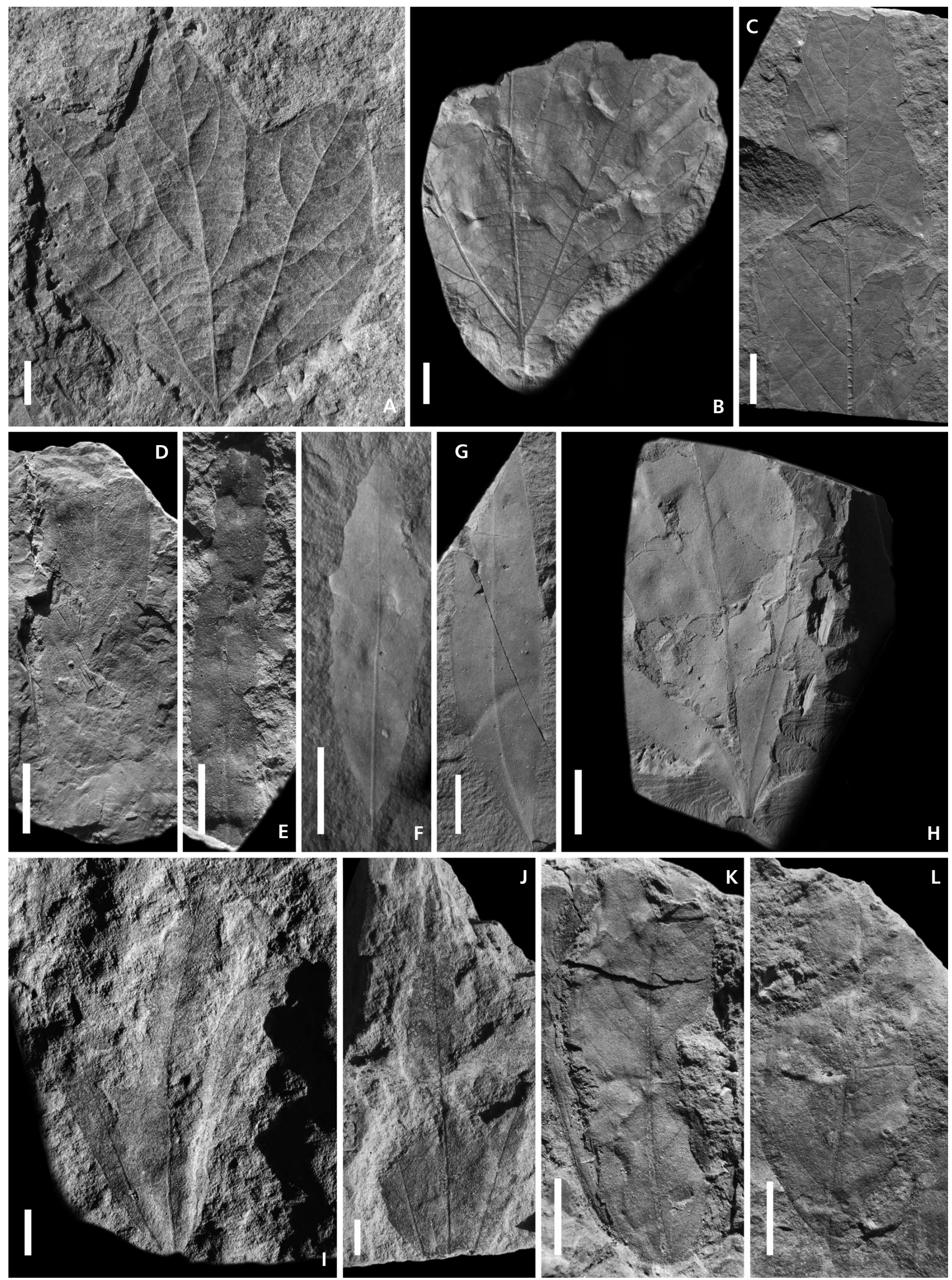
presence of the genus Saurauia limits the lowest temperature values for MAT and CMMT. The presence of the genus Liriodendron limits the highest temperature values for both MAT and CMMT. WMMT values determined range from $24^{\circ} \mathrm{C}$ to $28^{\circ} \mathrm{C}$. The genus Saurauia is again responsible for the lowest temperature values and the presence of the genus Sabia limits the highest temperature values. Mean annual precipitation values vary from 900 to $1600 \mathrm{~mm}$. This variable is limited by the genus Saurauia, which can only grow in areas with a very limited range of precipitation values. These values limit the interval of coexistence, which is the interval in which all of the discussed genera can grow.

These data are in general agreement with other studies carried out on Cretaceous floras. The results for coexistence analysis published by Uhl (2006) for Cretaceous floras are in very good agreement with our interpretations.

\section{Discussion}

As a basis for the present palaeoecological reconstruction, we used the CLAMP analysis. Methods of LMA and NLR were used for comparison and clarification of the results. The present work also revised the preliminary results of CLAMP by Herman et al. (2002), based on figured specimens by Němejc (1961) and Němejc \& Z. Kvaček (1975), who used it in their comparison with the flora of Grünbach. Preliminary data published by Herman et al. (2002) based on dataset of 103 modern vegetation sites are: MAT $15.6{ }^{\circ} \mathrm{C}$; WMMT $22.2{ }^{\circ} \mathrm{C}$; CMMT $9.0{ }^{\circ} \mathrm{C}$; GROWSEAS 8.7 months; GSP $780 \mathrm{~mm}$; MMGSP $88.6 \mathrm{~mm}$; 3-DRY $144.1 \mathrm{~mm}$ (Table 5).

In the present study, we analyzed all available data (more than 1000 specimens). The number of taxa and their variability allow employment of the CLAMP method, but we must take into account that the shortage of high quality fossils increases climate estimate deviation. Poor preservation (no cuticle or venation preserved) of some entire-margined leaves may have been responsible for low diversity, which could in turn produce quite low temperature values.

The results of CLAMP analyses were compared to the results gathered from LMA, NLR and coexistence methods. In general we agree with the preliminary data published by Herman et al. (2002), and by using two major approaches we were able to deduce the major palaeoclimatic parameters shown in Table 6.

The values of MAT (LMA: $18.5^{\circ} \mathrm{C}$, CLAMP: $15^{\circ} \mathrm{C}$, CoA: $15-21^{\circ} \mathrm{C}$ ) have a large range. This is most likely due to the poor preservation of the flora; however we accept a value for MAT of approximately $15{ }^{\circ} \mathrm{C}$. We put more emphasis on data obtained by CLAMP because it works with more characters than LMA.

The results for WMMT (CLAMP: $24{ }^{\circ} \mathrm{C}$, CoA: 24-28 ${ }^{\circ} \mathrm{C}$ ), CMMT (CLAMP: $\left.6{ }^{\circ} \mathrm{C}, \mathrm{CoA}: 5-15^{\circ} \mathrm{C}\right)$ and
GSP (CLAMP: 800, NLR: 900-1600 mm) are in agreement for both CLAMP and the coexistence approach. It is normal for LMA to give higher MAT values than CLAMP (compare Herman \& Kvaček 2007). However, in the present comparison, CoA also showed higher MAT values. It is striking that WMMT, CMMT and GSP values are in good agreement for all three methods used.

Based on the presence of frequent charcoals, we assume a seasonally dry climate for the Klikov ecosystem. Charcoal is commonly formed under natural conditions during wildfires (Falcon-Lang et al. 2001). Fires are common in the dry season of seasonally dry subtropical forests, where accumulated dead plant remains serve as a combustible material which easily burns.

\section{Summary}

For the palaeoclimatic interpretation of the Klikov Formation Flora (Upper Turonian-Santonian) leaves, fruits and seeds were used. We used the following methods: LMA, CLAMP and CoA. LMA and CLAMP are based on leaf physiognomy, the CoA is based on environmental requirements of the nearest living relatives of the fossil plants.

Mean annual temperature is estimated to have been approximately $15{ }^{\circ} \mathrm{C}$. Values obtained from CLAMP are $15^{\circ} \mathrm{C}$; values from LMA are $18.5^{\circ} \mathrm{C}$ and from the coexistence approach are $15-21{ }^{\circ} \mathrm{C}$. Results obtained using LMA are generally higher than in other analyses. Values obtained using the coexistence approach could be inconsistent due to a shortage of living relatives and their distant relationship to their Cretaceous ancestors. According to CLAMP and the coexistence approach, WMMT was approximately $24{ }^{\circ} \mathrm{C}$ and CMMT was approximately $6{ }^{\circ} \mathrm{C}$. Growing season precipitation is estimated to have been approximately $800 \mathrm{~mm}$.

\section{Acknowledgement}

We gratefully acknowledge receipt of Grant MK ČR DE07P04OMG005, which made this work possible. We thank Vasilis Teodoridis for help with Canonical Correspondence Analysis and Dieter Uhl for providing climatic data for recent genera. We thank Dieter Uhl and Alexey Herman for reviews which greatly improved the quality of the manuscript.

\section{References}

ANONYMUS 2008. Tropical seeds. Trade winds fruit. http://www.tradewindsfruit.com/order_fruit_m_z.htm

BAILEY, I.W. \& SinNOTT, E.W. 1915. A botanical index of Cretaceous and Tertiary climates. Science 41, 831-834. DOI $10.1126 /$ science.41.1066.831 
BECK, D.E. 1990. Liriodendron tulipifera L. yellow poplar, 406-416. In BURNS, R.M. \& HONKALA, B.H. (eds) Silvics of North America. Volume 2. Hardwoods. United States Department of Agriculture Forest Service, Washington.

Behera, M.D., Kushwaha, S.P.S., Roy, P.S., Srivastava, S., SingH, T.P. \& DUBEY, R.C. 2002. Comparing structure and composition of coniferous forests in Subansiri district, Arunchal Pradesh. Current Science 82(1), 70-76.

EtTingshausen, C. 1852. Über fossile Pflanzen bei Wittingau in Böhmen. Jahrbuch der kaiserlich-königliche geologische Reichsanstalt 1852, 144.

FRUMIN, S. \& FRIIS, E.M. 1999. Magnoliid reproductive organs from the Cenomanian-Turonian of north-western Kazakhstan: Magnoliaceae and Illiciaceae. Plant Systematics and Evolution 216, 265-288. DOI 10.1007/BF01084403

FALCON-LANG, H.J., KVAČEK, J. \& ULIČNÝ, D. 2001. Fireprone plant communities and palaeoclimate of a Late Cretaceous fluvial to estuarine environment, Pecínov quarry, Czech Republic. Geological Magazine 138(5), 563-576. DOI $10.1017 / \mathrm{S} 0016756801005714$

Hayes, P.A., Francis, J.E., Cantrill, D.J. \& Crame, J.A. 2006. Palaeoclimate analysis of Late Cretaceous angiosperm leaf floras, James Ross Island, Antarctica. Geological Society, London, Special Publications 258, 49-62.

HEER, O. 1855. Die tertiäre Flora der Schweiz: Criptogamen, Gymnospermen und Monocotyledonen. 117 pp. J. Wurster, Winterthur.

HEER, O. 1856. Die tertiäre Flora der Schweiz: Die apetalen Dicotyledonen. 110 pp. J. Wurster, Winterthur.

HEER, O. 1859. Die tertiäre Flora der Schweiz: Die gamopetalen und polypetalen Dicotyledonen. 377 pp. J. Wurster, Winterthur.

Herman, A.B. 2004. Quantitative paleobotanical data: constraints on Late Cretaceous climates in Eurasia and Alaska, 88-104. In LEONOV, I.G. (ed.) Klimat v epokhi krupnykh biosfernykh perestroek (Climates in the epochs of major biospheric transformations). Nauka.

Herman, A.B. \& KVAČEK, J. 2002. Campanian Günbach flora of Lower Austria, preliminary floristics and palaeoclimatology. Annales Naturhistorisches Museum, Wien 103A, 1-21.

HERMAN, A.B. \& KVAČEK, J. 2007. Early Campanian Grünbach flora of Austria: systematic composition and palaeoclimatic interpretations. Acta Palaeobotanica 47(1), 37-55.

HERMAN, A.B. \& SPICER, R.A. 1996. Palaeobotanical evidence for a warm Cretaceous Arctic Ocean. Nature 380, 330-333. DOI $10.1038 / 380330 \mathrm{a} 0$

HERMAN, A.B. \& SPICER, R.A. 1997. New quantitative palaeoclimate data for the Late Cretaceous Arctic: evidence for a warm polar ocean. Palaeogeography, Palaeoclimatology, $\mathrm{Pa}$ laeoecology 128, 227-251. DOI 10.1016/S0031-0182(96)00080-6

HERMAN, A.B., SPICER, R.A. \& KVAČEK, J. 2002. Late Cretaceous climate of Eurasia and Alaska: a quantitative palaeobotanical approach, 93-108. In WAGREICH, M. (ed.) Aspect of Cretaceous Stratigraphy and Palaeobiogeography. Österrische Akademie der Wissenschaften 15.
Kenedy, E.M., SPICER, R.A. \& REES, P.M. 2002. Quantitative palaeoclimate estimates from Late Cretaceous and Paleocene leaf floras in the northwest of the South Island, New Zealand. Palaeogeography, Palaeoclimatology, Palaeoecology 184, 321-345. DOI 10.1016/S0031-0182(02)00261-4

KNOBLOCH, E. 1964. Neue Pflanzenfunde aus dem südböhmischen Senon. Jahrbuch des Staatlichen Museums für Mineralogie und Geologie zu Dresden, 133-201.

KNOBLOCH, E. 1985. Paläobotanisch-biostratigraphische Charakteristik der Klikov-Schichtenfolge (Oberturon-Santon) in Südböhmen. Sborník geologických věd, Geologie 40, 101-145.

KNOBLOCH, E. \& MAI, D.H. 1984. Neue Gattungen nach Früchten und Samen aus dem Cenoman bis Maastricht (Kreide) von Mitteleuropa. Feddes Repert 95, 3-41.

KNOBLOCH, E. \& MAI, D.H. 1986. Monographie der Früchte und Samen in der Kreide von Mitteleuropa. Rozpravy Ústředního ústavu geologického 47, 1-219.

KNOBLOCH, E. \& MAI, D.H. 1991 Evolution of Middle and Upper Cretaceous floras in Central and Western Europe. Geologisches Jahrbuch Reihe A 134, 257-270.

KovaC, W.L. \& SPICER, R. 1995. Canonical Correspondence Analysis of Leaf Physiognomy: a Contribution to the Development of a new palaeoclimatological Tool. Palaeoclimates 1, $125-138$.

KVAČEK, J. \& VÁCHOVÁ, Z. 2006. Revision of platanoid foliage from the Cretaceous of the Czech Republic. Časopis Národního muzea, Řada prírodovědná 175(3-4), 77-89.

KVAČEK, Z. \& TEODORIDIS, V. 2007. Tertiary macrofloras of the Bohemian Massif: a review with correlations within Boreal and Central Europe. Bulletin of Geosciences 82(4), 383-408. DOI 10.3140/bull.geosci.2007.04.383

Malecha, A., ŠPINAR, Z., BOŘKOVÁ-GABRIElOVÁ, N., MrÁZEK, A., NĚMejC, F., PACltovÁ, B., ŘehÁKovÁ, Z. \& SLÁNSKÁ, J. 1962. Nové dělení a označení stratigrafických jednotek jihočeských pánví. Věstník Ústředního ústavu geologického 37(3), 161-170.

MAI, D.H. 1970. Funde von Saurauia Willd. im europaischen Alttertiar. Wissenschaftliche Zeitschrift der Friedrich-Schiller-Universität Jena, Mathematisch-Naturwissenschaftliche Reihe, 385-392.

Mosbrugger, V. 1999. The nearest living relative method, 261-265. In JOHNES, T.P. \& RowE, N.P. (eds) Fossil plants and spores: Modern techniques. The Geological Society, London.

Mosbrugger, V. \& UTESCHER, T. 1997. The coexistence approach - a method for quantitative reconstructions of Tertiary terrestrial palaeoclimate data using plant fossils. Palaeogeography, Palaeoclimatology, Palaeoecology 134, 61-86. DOI 10.1016/S0031-0182(96)00154-X

NĚMEJC, F. 1938. První nález křídové květeny v jihočeské pánvi. Časopis Národního muzea, Oddíl přirodovědecký 112, 167.

NĚMEJC, F. 1961. Fossil plants from Klikov in S. Bohemia (Senonian). Rozpravy Československé akademie věd, $\breve{R} a d a$ matematicko-přirodovědná 1(1), 1-48.

NĚMEJC, F. \& KVAČEK, Z. 1975. Senonin plant macrofossils 
from the region of Zliv and Hluboká (near České Budějovice). 82 pp. Univerzita Karlova, Praha.

NĚMEJC, F. \& PACLTOVÁ, B. 1956. Paleobotanické poznámky k profilům podél Nové Řeky východně od Třeboně. Časopis pro mineralogii a geologii 1(3), 232-242.

PAClTOVÁ, B. 1955. Mikropaleontologický výzkum v oblasti jihočeského terciéru. Zprávy o geologických výzkumech v roce 1954, 132-134.

PAClTOVÁ, B. 1958a. Palynologický výzkum křídových, terciérních a kvartérních hornin $\mathrm{v}$ jihočeských pánvích $\mathrm{v}$ roce 1956. Věstník Ústředního ústavu geologického 33, 330-338.

PACLTOVÁ, B. 1958b. Zajímavé výsledky palynologického výzkumu strukturního vrtu z Budějovické pánve. Časopis pro mineralogii a geologii 3(4), 419-421.

PAClTovÁ, B. 1961. Některé rostlinné mikrofosilie ze sladkovodních uloženin svrchní křídy (senon) v jihočeských pánvích I. Sborník Ústředního ústavu geologického, Oddíl palontologický 26, 47-102.

PACLTOVÁ, B. 1981. The evolution and distribution of Normapolles pollen during the Cenophytic. Review of Palaeobotany and Palynology 35, 175-208. DOI 10.1016/0034-6667(81)90108-1

SLÁNSKÁ, J. 1974. Continental Cretaceous and Tertiary Sedimentation in the South Bohemian Basin. Neues Jahrbuch für Geologie und Paläontologie, Abhandlung 146(3), 385-406.

SLÁNSKÁ, J. 1976. A red-bed formation in the South Bohemia Basin, Czechoslovakia. Sedimentary Geology 15(2), 135-164. DOI 10.1016/0037-0738(76)90041-5

SoEJARTO, D.D. 1980. Revision of South American Saurauia (Actinidiaceae). Fieldiana, N.S. 2, 1-141.

SPICER, R.A. 2000. Leaf physiognomy and climate change, 244-264. In Culver, S.J. \& RAwson, P. (eds) Biotic response to global change: The last 145 million years. Cambridge University Press.

SPICER, R.A. 2006. Clamp. http://www.open.ac.uk/earth-research/spicer/CLAMP/Clampset1.html

ŠEvČíK, J., KVAČEK, Z. \& MAI, D.H. 2007. A new mastixioid florula from tektite-bearing deposits in South Bohemia, Czech Republic (Middle Miocene, Vrábče Member). Bulletin of Geosciences 82(4), 429-436. DOI 10.3140/bull.geosci.2007.04.429

TER BRAAK, C.J.F. 1986. Canonical correspondence Analysis: a new eigenvector technique for multivariate direct gradient analysis. Ecology 67, 1167-1179. DO] 10.2307/1938672
UHL, D. 2006. Fossil plants as palaeoenvironmental proxies some remarks on selected approaches. Acta Palaeobotanica 46(2), 87-100.

Uhl, D., Klotz, S., Traiser, C., Thiel, C., Utescher, T., KowALSKI, E. \& DILCHER, D. 2007. Cenozoic paleotemperatures and leaf physiognomy - A European perspective. Palaeogeography, Palaeoclimatology, Palaeoecology 248 (2007), 24-31. DOI 10.1016/j.palaeo.2006.11.005

UTESCHER, T. 2006. Palaeoflora database. http://www.palaeoflora.de/

WILF, P. 1997. When are leaves good thermometers? A new case for Leaf Margin Analysis. Paleobiology 23, 373-390.

WiLf, P., Wing, S.L., GreENwoOd, D.R. \& GREENwOOD, C.L. 1998. Using fossil leaves as paleoprecipitation indicators: An Eocene example. Geology 26, 203-206. DOI 10.1130/0091-7613(1998)026<0203:UFLAPI >2.3.CO;2

WING, S.L. \& GREENWOOD, D.R. 1993. Fossils and fossil climate: the case for equable continental interiors in the Eocene. Philosophical Transactions of the Royal Society of London, B 341, 243-252. DOI 10.1098/rstb.1993.0109

WolfE, J.A. 1979. Temperature Parameters of humid to Mesic Forests of Eastern Asia and Relation to forests of Other Regions of the Northern Hemisphere and Australasia. U.S. Geological Survey Professional Paper 1106, 1-37.

WOLFE, J.A. 1990. Palaeobotanical evidence for a marked temperature increase following the Cretaceous/Tertiary boundary. Nature 343, 153-156. DOI 10.1038/343153a0

WOLFE, J.A. 1993. A method of obtaining climatic parameters from leaf assemblages. U.S. Geological Survey Bulletin 2040, $1-73$.

WolFE, J.A. 1995. Paleoclimatic estimates from Tertiary leaf assemblages. Annual Review of Earth and Planetary Sciences 23, 119-142.

DOI 10.1146/annurev.ea.23.050195.001003

WOLFE, J.A. \& SPICER, R.A. 1999. Fossil Leaf Character States: Multivariate Analysis, 233-239. In JONES, T.P. \& ROWE, N.P. (eds) Fossil plants and spores: Modern techniques. Geological Society, London.

YANG, J., WANG, Y., SPICER, R., MosbrugGer, V., LI, C. \& SUN, Q. 2007. Climatic reconstruction at the Miocene Shanwang basin, China, using leaf margin analysis, CLAMP, coexistence approach, and overlapping distribution analysis. American Journal of Botany 94(4), 599-608.

DOI 10.3732/ajb.94.4.599 